\title{
Revisiting the Phillips Curve and the Lucas Critique
}

\author{
Md. Sharif Hossain ${ }^{1},{ }^{*}$ Rajarshi Mitra ${ }^{2}$ \\ 1University of Dhaka, Dhaka, Bangladesh \\ ${ }^{2}$ Kyushu University, Higashi-ku, Fukuoka-shi, Japan \\ *rmitra200@gmail.com
}

\begin{abstract}
Many OECD countries are facing problems of high government debt and high unemployment. Consequently, a monetary stimulus is being increasingly viewed as a solution to curb the rising debt burden and stimulate economic growth. Some OECD countries are setting inflation target at $2 \%$ or even higher. In this paper we investigate the likely impact of inflation on unemployment for a panel of 10 highincome OECD countries, namely, Australia, Denmark, Iceland, Japan, Korea, New Zealand, Norway, Sweden, Switzerland and the United States. The period of study is 1970-2012. Results indicate a significantly positive long-run impact of inflation on unemployment. Granger causality indicates long-run bi-directional causality between inflation and unemployment. For the 10 OECD countries and the period of this study, the empirical findings support the Lucas critique: inflation and unemployment are positively correlated. A monetary stimulus, therefore, will most likely aggravate the unemployment scenario in the 10 OCED countries under study.
\end{abstract}

Keywords: Inflation, Unemployment, Unit Root Tests, Cointegration, Granger Causality

\section{Introduction}

Many OECD countries are currently facing problems of high government debt and high unemployment. Due to the political difficulties associated with tax increases and spending cuts, a monetary stimulus is being increasingly viewed as an alternative means to curb the rising government debt and stimulate economic growth. It is believed that a monetary expansion will reduce the real value of the debt burden through an inflationary effect. Some OECD countries like Australia and Japan are setting the inflation target at 2\%. In the United States, there are suggestions to raise the target to almost 4\%. But high inflation due to a monetary stimulus will most likely have some impact on unemployment in OECD countries from changes in real wages. The theoretical relation between inflation and unemployment is well documented in macroeconomic literature. While the Phillips curve affirms an inverse relation between inflation and unemployment, according to the Lucas critique, the long-run inflation-unemployment relation is expectedly positive. This would happen if the policymakers try to exploit the trade-off between inflation and unemployment by implementing an expansionary monetary policy, in which case high inflation would be followed by high unemployment in the long-run. Thus, inflation may either lower unemployment or further aggravate the unemployment scenario. Since the impact of inflation on unemployment can either be positive or negative, an empirical investigation into the relation between the two variables is important from a policy standpoint. Although a vast body of empirical studies has examined this relation, the results have varied greatly across countries and groups of countries, and also across the different time periods under study. In this paper we investigate the inflation-unemployment relation for a group of 10 high-income OCED countries, namely, Australia, Denmark, Iceland, Japan, Korea, New Zealand, Norway, Sweden, Switzerland and the United States. We identify both the cointegrating relations and the direction of causality between inflation and unemployment for the period 1970-2012. In Section 2 we present a literature review; in Section 3 we discuss the data source and the method used for the cointegration and causal analysis; in Section 4 we present the results of the unit root tests, Granger causality, short-run and long-run effects of inflation on unemployment; in Section 5 we present the concluding remarks and policy implications.

\section{Literature Review}

Numerous studies have examined the relation between inflation and unemployment and the results are mostly mixed. Some notable studies providing evidence of a negative relation between inflation and unemployment include Phillips (1958), Karanassou et al. (2003), Franz (2005) and Schreiber and Wolters (2007). These studies support the Phillips curve. On the other hand, Phelps (1967), Friedman (1968), Lucas (1976), Beyer and farmer (2007), Berentsen et al. (2008) and Haq et al. (2012) found evidence of a 
positive inflation-unemployment relation. These studies support the Lucas critique that an increase in expected inflation will induce the workers to demand higher wages thereby causing real wages to rise and, in effect, high unemployment. In light of this mixed and inconclusive evidence we examine the cointegrating and causal relationships between inflation and unemployment for 10 high-income OECD countries.

\section{Methodology}

Data: This study uses annual time series data for 10 high-income OECD countries, namely, Australia, Denmark, Iceland, Japan, Korea, New Zealand, Norway, Sweden, Switzerland and the United States. The period of study is 1970-2012. The two variables of interest are consumer price index as a measure of inflation (with 2005 as the base year) and unemployment level (measured in thousands). The two variables in the model are indexed as CPI and UNM, respectively. The data source is OECD Statistics.

The Model: We examine the sensitivity of unemployment to changes in CPI by estimating the following model:

(1) $\mathrm{UNM}_{\mathrm{it}}=\mathrm{A}_{0} \mathrm{CPI}_{\mathrm{it}}^{\alpha_{1}} \mathrm{e}^{\varepsilon_{\mathrm{it}}}$

A logarithmic transformation of (1) gives:

(2) $\operatorname{lnUNM} M_{i t}=\alpha_{0}+\alpha_{1} \operatorname{lnCPI}_{i t}+\varepsilon_{i t}$

Estimation Method: The model is estimated in three steps: first, four unit root tests, namely, Levin, Lin and Chu (LLC, 2002), Im, Peasaran and Shin (IPS, 2003), Maddala and Wu (MW, 1999) and Choi (2006) are performed at both levels and first differences in order to examine stationarity of InCPI and lnUNM; second, cointegrating relationships between $\operatorname{lnCPI}$ and lnUNM are examined by performing the Kao (1999) and Johansen cointegration tests; third, if a cointegrating relationship between the panel variables is found to exist, then an error correction model is estimated to examine the causal relationships between the two panel variables. The short-run and long-run effects of inflation and unemployment are also examined and reported.

\section{Results}

Table 1: Results of Unit Root Tests

\begin{tabular}{|c|c|c|c|c|c|c|c|c|}
\hline \multicolumn{9}{|c|}{ Constant and Trend [Level] } \\
\hline & LLC & prob. & IPS & prob. & MW & prob. & Choi & prob. \\
\hline InCPI & $-4.21 *$ & 0.00 & 0.09 & 0.53 & 22.54 & 0.31 & 0.48 & 0.68 \\
\hline $\ln U N M$ & -0.89 & 0.19 & -0.26 & 0.39 & 17.27 & 0.64 & -0.24 & 0.40 \\
\hline \multicolumn{9}{|c|}{ Constant Only [First Difference] } \\
\hline & & prob. & IPS & prob. & MW & prob. & Choi & prob. \\
\hline$\Delta \operatorname{lnCPI}$ & $-2.14 *$ & 0.02 & $-2.23 *$ & 0.01 & $35.17 *$ & 0.02 & $-2.04 *$ & 0.02 \\
\hline$\Delta \operatorname{lnUNM}$ & $-8.73^{*}$ & 0.00 & $-10.26^{*}$ & 0.00 & 145.13* & 0.00 & $-9.49 *$ & 0.00 \\
\hline
\end{tabular}

The variables $\operatorname{lnCPI}$ and $\ln U N M$ were found to be non-stationary in level form, but the null hypothesis of a unit root was rejected by taking the first-difference. Both InCPI and InUNM are, thus, integrated of order one.

Panel Cointegration Tests: The cointegration tests are performed with one lag and the results are reported in Table 2. 


\begin{tabular}{|c|c|c|c|c|}
\hline \multicolumn{5}{|l|}{ Kao Test } \\
\hline & $-4.8822^{*}$ & & 0.0000 & \\
\hline \multicolumn{5}{|c|}{ Johansen Test: Model 1 (intercept (with no trend) in CE and VAR) } \\
\hline $\begin{array}{l}\text { Cointegrating } \\
\text { Equations }\end{array}$ & $\begin{array}{l}\text { Fisher Statistic } \\
\text { (Trace Test) }\end{array}$ & probability & $\begin{array}{l}\text { Fisher Statistic } \\
\text { (Max.Eigenvalue) }\end{array}$ & probability \\
\hline none & $141.3^{*}$ & 0.000 & $88.87^{*}$ & 0.000 \\
\hline maximum 1 & $109.4^{*}$ & 0.000 & $109.4^{*}$ & 0.000 \\
\hline \multicolumn{5}{|c|}{ Johansen Test: Model 2 (intercept and trend in CE but no trend in VAR) } \\
\hline $\begin{array}{l}\text { Cointegrating } \\
\text { Equations }\end{array}$ & $\begin{array}{l}\text { Fisher Statistic } \\
\text { (Trace Test) }\end{array}$ & probability & $\begin{array}{l}\text { Fisher Statistic } \\
\text { (Max.Eigenvalue) }\end{array}$ & probability \\
\hline none & $95.80 *$ & 0.000 & $70.17^{*}$ & 0.000 \\
\hline maximum 1 & $47.71^{*}$ & 0.000 & $47.71^{*}$ & 0.000 \\
\hline
\end{tabular}

*indicates test statistics that are significant at $1 \%$.

The results of both Kao (1999) ADF type test and Johansen Fisher panel cointegration test as proposed by Maddala and Wu (1999) confirm cointegrating relationships between InCPI and lnUNM.

Granger Causality: An augmented form of the Granger causality test in a multivariate VECM framework is represented in the following form:

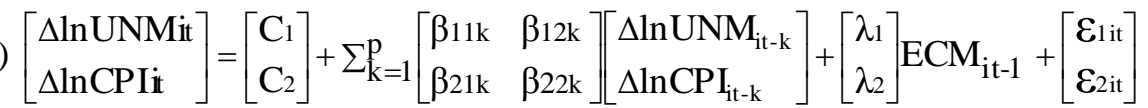

An ECM term is included in the VAR system to examine the long-run causal relationships between lnCPI and lnUNM. The results of the Engle and Granger (1987) test, performed on the first- differenced variables, are reported in Table 3.

Table 3: Granger Causality

\begin{tabular}{lccc}
\hline & $\Delta \operatorname{lnCPI}$ & $\Delta \ln U N M$ & ECM \\
\hline \multirow{2}{*}{$\Delta \operatorname{lnCPI}$} & & $2.53^{*}$ & $-4.12^{*}$ \\
& & $(0.021)$ & $(0.000)$ \\
\multirow{2}{*}{$\Delta \ln \mathrm{NNM}$} & $4.69^{*}$ & & $2.16^{*}$ \\
& $(0.000)$ & & $(0.032)$ \\
\hline
\end{tabular}

*indicates test statistics and coefficients that are significant at $1 \%$.

The Granger causality test results indicate short-run bidirectional causality between lnCPI and lnUNM. Results also indicate long-run causal link between the two variables.

The short-run and long-run elasticities of lnUNM with respective to a change in lnCPI are obtained by estimating (4) and (5) respectively:

(4) $\Delta \ln \mathrm{UNM}_{\mathrm{it}}=\beta_{1} \Delta \ln \mathrm{CPI}_{\mathrm{it}}+\lambda \mathrm{ECM}_{\mathrm{it}-1}+\varepsilon_{\mathrm{it}}$

(5) $\ln \mathrm{UNM}_{\mathrm{it}}=\beta_{0}+\beta_{1} \ln \mathrm{CPI}_{\mathrm{it}}+\sum_{\mathrm{j}=1}^{\mathrm{p}} \gamma_{\mathrm{ij}} \Delta \operatorname{lnCPI} \mathrm{I}_{\mathrm{it}-\mathrm{j}}+\mu_{\mathrm{it}}$

In equation (4), both InCPI and lnUNM are introduced in first-differenced form. The speed of convergence towards long-run equilibrium is given by the coefficient $\lambda$. In equation (5), the coefficient $\beta_{1}$ measures the long-run sensitivity of lnUNM to changes in InCPI. Both AIC and SBIC are used to determine the optimum lag-length. The GMM technique is then applied to estimate the short-run and long-run elasticity coefficients in (4) and (5), respectively. The short-run and long-run coefficients are reported in Table 4 and Table 5, respectively. 
Table 4: Short-Run Coefficients

\begin{tabular}{lcl}
\hline & $\Delta \operatorname{lnCPI}$ & ECM \\
\hline coefficient & 0.54 & 0.01 \\
probability & 0.00 & 0.49 \\
\hline
\end{tabular}

The short-run coefficient of 0.54 is positive but statistically insignificant, thereby indicating lack of any significant impact of inflation on unemployment at least in the short-run. The adjustment coefficient of 0.01 , although positive, is also statistically insignificant. These rules out the possibility of any significant divergence from long-run equilibrium.

Table 5: Long-Run Coefficients

\begin{tabular}{lc}
\hline \multicolumn{2}{c}{$\operatorname{lnCPI}$} \\
\hline coefficient & $0.54^{*}$ \\
probability & 0.03 \\
\hline *indicates coefficients that are significant at $1 \%$.
\end{tabular}

The long-run coefficient of 0.54 is positive and statistically significant at $1 \%$ level. The long-run coefficient indicates that, for every $1 \%$ increase in CPI, unemployment in the economy will increase by $0.54 \%$. Thus, a significantly positive long-run relation between inflation and unemployment is observed for the 10 OECD countries. This empirical finding, thus, supports the Lucas critique instead of the Phillips curve.

\section{Conclusion}

This paper, using dynamic panel cointegration and causal analysis, has examined the sensitivity of unemployment to changes in inflation for 10 high-income OECD countries for the period 1970-2012. Granger causality indicates long-run bi-directional causal link between inflation and unemployment. The cointegration tests confirm long-run relationships between the variables. Although the short-run relation is found to be statistically insignificant, the long-run impact of inflation on unemployment is significantly positive. Results indicate that, for every 1\% rise in CPI, unemployment in the 10 OECD countries will rise by $0.54 \%$. For the 10 OECD countries it can, therefore, be concluded that, if the policymakers implement an expansionary monetary policy in order to reduce government debt and stimulate economic growth, then as long as nominal wages remain fixed, high inflation will not have any significant impact on unemployment at least in the short-run. However, as nominal wages adjust to price increases in the longrun, real wages will eventually rise and lead to a fall in the demand for labor; consequently, inflation and unemployment will exhibit a positive correlation and no permanent trade-off will exist between the two variables. Thus a monetary stimulus, in the long-run, will most likely aggravate the unemployment scenario in the 10 OECD countries. The dynamic panel analysis adopted in this study was applied to a group of 10 high-income OECD countries. It might be interesting to extend the panel analysis to a countryspecific comparative study and examine the inflation-unemployment relation for each of the 10 OCED countries covered in this study.

\section{References}

Berentsen, A., Menzio, G. \& Wright, R. (2008). Inflation and unemployment in the end. Working Paper 13924, National Bureau of Economic Research.

Beyer, A. \& Farmer, R. E. (2007). Natural rate doubts. Journal of Economic Dynamics and Control, 31(3), 797-825.

Choi, I. (2006). Combination Unit Root Tests for Cross-Sectionally Correlated Panels. Econometric Theory and Practice: Frontiers of Analysis and Applied Research, Cambridge University Press: 311-333.

Engle, R. F. \& Granger, C. W. J. (1987). Cointegration and Error Correction: Representation, Estimation and Testing. Econometrica, 55(2), 251-276.

Franz, W. (2005). Will the (German) NAIRU Please Stand Up? German Economic Review, 6(2), 131-153.

Friedman, M. (1968). The Role of Monetary Policy. American Economic Review, 58(1), 1-17.

Haq, U., Khan, S., Khan, A. \& Ahmed, E. (2012). Phillips Curve or Locus Critique: Time Series Evidence from Pakistan. Journal of Economics and Behavioral Studies, 4(4), 190-193.

Im, K., Pesaran, M. H. \& Shin, Y. (2003). Testing for Unit Roots in Heterogeneous Panels. Journal of Econometrics, 115(1), 53-74.

Kao, C. (1999). Spurious regression and residual-based tests for cointegration in panel data. Journal of Econometrics, 90(1), 1-44. 
Karanassou, M., Sala, H. \& Snower, D. J. (2003). The European Phillips Curve: Does the nairu exist? IZA Discussion Papers 876, Institute for the Study of Labor (IZA).

Levin, A., Lin, C. \& Chu, C. J. (2002). Unit Root Tests in Panel Data: Asymptotic and Finite Sample Properties. Journal of Econometrics, 108(1), 1-24.

Lucas, R. E. (1976). Econometric Policy Evaluation: A Critique. Carnegie-Rochester Conference Series on Public Policy, 1(1), 19-46.

Maddala, G. S. \& Wu, S. (1999). A comparative study of unit root tests with panel data and new simple test. Oxford Bulletin of Economics and Statistics, 61(S1), 631-652.

Phelps, E. (1967). Phillips Curve, Expectation of Inflation, and Optimal Inflation over Time. Economica, 34(135), 254-281.

Phillips, A. W. (1958). The Relationship between Unemployment and the Rate of Change of Money Wage Rates in the United Kingdom. Economica, 25, 258-299.

Schreiber, S. \& Wolters, J. (2007). The long-run Phillips curve revisited: Is the Nairu framework dataconsistent? Journal of Macroeconomics, 29(2), 355-367. 